\title{
Analysis on the Current Situation and Ways of the Construction of Double-Qualified Teachers in Higher Vocational Tourism Management
}

\begin{abstract}
Yongle Chen
Jiangxi Vocational Technical College of Industry \& Trade, Jiangxi, Nanchang,330038

3107000933@qq.com

ABSTRACT

In higher vocational colleges of core competitiveness is the talent cultivation of ability and the ability of academic research, and higher vocational tourism management professional is not exceptional also, in the tourism management specialty in higher vocational colleges to teacher's double training to the professional development plays an important role in ascension, through double teachers to create and develop, can play a play of great help to talents training in higher vocational colleges, so the tourism management specialty in higher vocational colleges should not only strengthen the ability of academic research, should also strengthen the ability of personnel training, and higher vocational tourism management should also make a certain contribution to the development of tourism. This paper also focuses on the current situation of the construction of double-qualified teachers in higher vocational tourism management major and analyzes the ways to improve the construction level of double-qualified teachers.
\end{abstract}

Keywords: Higher vocational tourism management major, double-qualified teachers, construction

\section{高职旅游管理专业双师型师资队伍建设现状与途径 分析}

陈永乐

\author{
江西工业贸易职业技术学院 江西 南昌 330038 \\ 3107000933@qq.com
}

\section{摘要}

高职院校的核心竞争力也就是人才培养的能力以及学术研究的能力, 而高职旅游管理专业也不例外, 在高职院 校旅游管理专业中对教师的双师型培养对该专业的发展起着重要的提升作用, 通过双师型教师队伍的创建和 培养, 能够起到对高职院校的人才培养起到很大的帮助, 因此高职院校旅游管理专业不仅应该加强学术研究的 能力, 也应该加强人才培养能力, 而高职旅游管理专业也应该为旅游业的发展做出一定的贡献。本文也主要围 绕高职旅游管理专业双师型师资队伍建设的现状以及提升双师型师资队伍建设水平的途径进行分析。

关键词：高职旅游管理专业；双师型师资队伍；建设

\section{1. 旅游管理专业中对教育人才的需求}

随着当今社会的不断发展, 我国国民经济水平得 到了极大的提升, 信息技术也逐渐发展成熟, 人们的 生活水平得到了质的提升, 旅游行业的发展也逐渐繁
荣起来, 在这种背景下对旅游业的高素质专业人才的 需求也越来越多, 无论是企业还是社会都对旅游行业 的人才产生了一定的诉求, 这种诉求产生的原因主要 是当下旅游行业虽说有很多从业人员，但在从业者的 质量上还远远达不到社会需求，因此，高校在培养旅 
游管理的高素质人才上起着重要作用, 其中高职院校 旅游管理专业所需人才应当具备良好的道德素养, 这 是最基本的专业素养, 只有教育者自身的素养得到提 升, 才能在高职院校的专业教学的课堂中让学生产生 学习的动力, 教师在教学过程中才能起到一个好的带 头作用, 同时由于旅游行业的特点, 教师必须要对当 下互联网信息时代下的旅游行业的发展有一定的了 解, 这样才能从实际中去培养学生的专业素养。

\section{1. 基本语言素养}

在旅游管理专业中, 双师型任课教师首先需要具 备最基本的语言能力, 这种语言能力不仅仅是指日常 生活用语, 其中还包括旅游专业上的身体语言、书面 化语言的规范用语等等旅游专业所需具备的语言能 力, 此外还有一些导游所需具备的一些语言沟通表达 能力, 这也是十分重要的语言能力, 这些都是旅游管 理专业双师型教师所需具备的基本的语言能力。

\section{2. 旅游管理专业基础知识}

旅游管理专业需要掌握行业多方面、多角度的知 识, 其中包含了市场营销理论知识、旅游行业中现有 的法律法规、各种旅游景点业务的了解、当下旅游行 业发展的趋势、目前旅游市场上各类旅游项目, 还有 各种旅游公司的运营模式和各种流程等等, 旅游行业 中对人才的培养需要综合性培养, 只有教育者有着多 方面的领域的了解才能培养出高素质旅游业人才。

\section{3. 实践操作能力}

在旅游管理行业中, 想要培养 “双师型” 教育人 才, 首先教育工作者不仅仅要具备基本的专业理论知 识, 同时也要有相应丰富的实践能力, 比如在实践中 要能够承担起对旅行社、旅游景点的管理、人员的培 训等等, 通过这些实践经验指导学生对专业基础知识 进行相应的实践教学, 更好的引导学生。

\section{4. 相关职业技能的拓展}

旅游行业 “双师型” 教师不仅仅需要在课堂中讲 授教材中的理论知识, 同时还要有过硬的职业实践技 能, 在旅游业相关领域能够进行行业的实践能力的实 践训练, 对学生将来走入工作岗位能够起到一定的指 导作用, 从就业实践方向入手传授学生相关的行业知 识, 比如旅游行业中的行业调研知识、课程开发和基 本的科研能力等等, 只有同时紧抓双师型教师的专业 理论知识和实践能力, 才能够让学生能够更快地适应 工作岗位, 满足行业的发展需要, 找到更加符合预期 的工作。

\section{2. 高职旅游管理专业双师型师资队伍建设 的重要意义}

高职旅游管理专业需要满足职业教育所提出的 需求, 同时也需要具备高等教育的属性, 因此高职旅 游管理专业教师应该具备扎实的理论功底, 同时也要 具备一定的实践操作能力。但是就从目前的高职旅游 管理专业人才培养效果来看, 大部分学生都仅仅只是 具备了一定的理论基础, 但是却十分缺乏实践能力, 而这也与教师的教育教学过程有关。因为在旅游管理 专业教学中, 教师更加注重理论教学, 也更加看重学 生对知识的掌握, 而对于学生对知识的应用却有所忽 略。不过当下也已经有了大部分高职院校意识到了这 一问题, 开始提升技能课在旅游管理专业课程体系中 的比重。而旅游管理专业技能课与其他专业的技能课 不同之处在于旅游管理专业课中教师所需要讲解的 不仅是专业实践知识, 也是学生在旅游管理专业方向 岗位中所必须要具备的知识和技能。所以能够对学生 进行实践教学的教师必须是具备一定实践经验的教 师, 但是由于大部分旅游管理专业教师都是师范学校 毕业又或是旅游管理专业应届毕业生, 十分缺乏实践 经验, 甚至有部分教师完全没有实践经验。那么也因 为这个原因, 学生能够在教师处得到的实践指导是有 限的, 而这也影响了高职院校旅游管理专业人才培养 质量的提升, 而之所以要建设双师型教师队伍, 就是 为了推动高职院校旅游管理专业教育教学的发展, 并 提升高职院校旅游管理专业人才培养的质量和效率。 教师的教学成果与学生的学习成果有着直接的联系, 如果教师的教学能力有限, 能够为学生带来的帮助也 有限, 那么学生在教学中所能够得到的收获也是有限 的。

建设高职院校的旅游管理专业的师资队伍难度 是非常大的, 因为当前市场上也非常缺乏旅游管理专 业的复合型人才, 而真正具备一定的知识水平和实践 能力的人才, 也不一定愿意投身教育行业。并且高职 院校的薪资水平只处于中等水平, 缺乏灵活性。大部 分旅游管理专业人才为了追求更高的薪资待遇, 会选 择进入国企或外企等用人单位, 因此高职院校在引进 双师型教师方面也困难重重。所以当前高职院校也必 须对此问题进行深入的思考, 只有解决了这个问题, 才能够为高职院校带来更多的人才资源, 才能够利用 人才资源推动高职院校教育教学的发展。近几年高职 院校也一直在对旅游管理专业人才培养模式以及教 育教学模式进行改革创新。但是如果教师的质量跟不 上改革的速度, 满足不了创新的要求。那么通过改革 和创新, 能够为高职院校旅游管理专业带来的提升也 是有限的。

高职旅游管理专业的双师型教师的培养区别于 对普通教师的培养, 在旅游管理专业双师型教师的建 设中要注重对教师的实践能力的培养, 双师型教师不 仅仅需要具备丰富的旅游管理专业的理论知识, 同时 还要具备丰富的实践能力, 为学生将来步入工作岗位 
奠定一个良好的基础, 只有对教师进行专业的培养, 才能在学生的专业水平上起到有力的帮助作用, 但当 今高职院校的旅游管理专业教师大部分都是理论知 识丰富, 实践经验不足的状态, 因此高职院校需要对 高素质双师型人才进行相应的引进，同时做好教师的 培养工作，对旅游管理专业教师进行鼓励和支持，只 有教师自身的专业素养有所提升, 学生才能在课堂中 获得行业发展中的真实需求。因此教师也要努力提升 自身的专业能力和基本素养, 同时也要提升自己的教 学水平, 更好的引导学生进行专业上的学习。

\section{3. 高职旅游管理专业双师型师资队伍建设 的途径}

表 1 高职旅游管理专业双师型师资队伍建设的途径

高职旅游管理专业双师型师资队伍建设的途径

\begin{tabular}{|c|c|c|}
\hline 人事分配 & 人员录用 & 兼职教师 \\
\hline $\begin{array}{l}\text { “双师素质” } \\
\text { 教师的岗位津 } \\
\text { 贴可略高于实 } \\
\text { 际职称职级, } \\
\text { 而他们的超课 } \\
\text { 时律贴也可以 } \\
\text { 在原有课时数 } \\
\text { 的基础上, 按 } \\
\text { 照一定的系数 } \\
\text { 予以计算, 以 } \\
\text { 调动 “双师素 } \\
\text { 质” 教师的工 } \\
\text { 作积极性。 }\end{array}$ & $\begin{array}{l}\text { 在新进教师中, 每 } \\
\text { 年保证要有从行 } \\
\text { 业、企业调入的技 } \\
\text { 能人员。他们的学 } \\
\text { 历要求可适当放 } \\
\text { 宽: 一般人员要求 } \\
\text { 术科以上; 特殊人 } \\
\text { 才如行业公认的技 } \\
\text { 术大师或专家、学 } \\
\text { 校专业发展急需人 } \\
\text { 才可放宽到专科, } \\
\text { 与目前的技能型课 } \\
\text { 程师资一般要求硕 } \\
\text { 士研究生的传统标 } \\
\text { 准相比, 可下降一 } \\
\text { 到两个层次。 }\end{array}$ & $\begin{array}{l}\text { 兼职教师聘 } \\
\text { 用管理可以 } \\
\text { 实行灵活多 } \\
\text { 样的政策, } \\
\text { 一切围绕学 } \\
\text { 生发展的需 } \\
\text { 求、专业建 } \\
\text { 设的需求, } \\
\text { 聘请学校需 } \\
\text { 要的企业专 } \\
\text { 业技术人 } \\
\text { 才, 实行管 } \\
\text { 理多样化, } \\
\text { 授课形式多 } \\
\text { 样化。 }\end{array}$ \\
\hline
\end{tabular}

\section{1. 人事分配}

为了能够吸引更多的具备专业能力又具备实践 经验的旅游管理专业人才投身到教育事业中, 高职院 校在人事分配中应该更加倾向于双师型教师。并提升 双师型教师的岗位津贴, 从物质方面来调动双师型教 师的教学热情, 而面对同企业中转行的双师型教师, 高职院校也应该尽可能地减少其在企业中与在学校 中所得到的工资的差距, 以此减少人才的损失, 将优 秀的教学人才留在高校, 为建设双师型人才提供保障。

\section{2. 人员录用}

面对旅游管理专业复合型人才, 高职院校应该对 其的学历进行适当的放宽, 因为在教育教学过程中, 所更加重视是教师的教学能力和专业能力, 而不是教
师的学历, 虽然教师的学历能够体现出一部分教师的 能力, 但是并不能完全代表教师的能力。因此为了推 动学校的发展, 提高学校的实践教学水平, 给予学生 更多的实践指导, 高职院校在面对旅游管理专业复合 型人才时，应该下放学历标准。

\section{3. 兼职教师}

如果专职教师还不能够满足学校教育教学的发 展需求, 学校就可以设置兼职教师的管理制度, 招收 更多的兼职教师, 往往学校所招收的兼职教师大部分 都是企业中的领导层人物, 又或是企业中专业的技术 人才, 无论是领导的人物还是专业技术人才, 都能够 给学生带来更多的帮助, 同时也会给教学课堂带来更 多的可变化性, 因为教师的教学方式是具有固定性的, 而这些专业人才的教学方式是存在多变性的, 所以通 过这些专业人才或是领导层人物的帮助, 学生不太能 够更加深入的了解旅游管理方面的知识, 也会对旅游 管理产生更加浓厚的兴趣, 而学校也可以跟旅游企业 建立校企合作关系，一方面旅游企业中的专业人才能 够旅游管理专业教学作出一定的指导, 另一方面, 学 校也可以为旅游企业提供更多的旅游管理专业人才, 充实企业的人才资源。而面对兼职教师的管理问题, 学校应该建立数据库, 对兼职教师做好详细和全面的 调查, 并且在聘用兼职教师时, 也应该明确兼职教师 的兼职时间以及考核方式。虽然兼职教师的时间没有 职业教师的时间固定，但是也必须要保证兼职教师的 稳定性, 不能因为兼职教师的随意而影响到了学校教 育教学工作的质量。而兼职教师的存在也能够为高职 院校招生教师队伍进行补充。

\section{4. 完善教师培养制度}

双师型教师由于性质和普通教师之间的差异, 双 师型教师本身就无法应用普通教师传统的制度进行 考核和培养, 建立一个新的教师培养体系就显得十分 必要, 包括新的教师培养体系和对教师的考核体系, 在构建新的制度时不能再仅仅考虑到教师的学历和 专业学科的水平，应该多方面进行考虑，比如教师的 理论知识水平和实践能力以及职业经历等等多方面 进行考核。

\section{5. 鼓励教师提升专业素养}

高职旅游管理专业的双师型教师的培养需要高 校进行一定的鼓励，鼓励教师参加社会实践，进入企 业提升自身的专业技能，同时丰富自身的岗位实践经 验, 对当下行业中的最新的技术进行掌握, 并将这些 最新的技术应用到教学课程中去, 同时提升旅游管理 专业的技术水平，教师也可以将这些新技术应用到旅 游企业中去。 


\section{4. 结论}

综上所述，建设双师型教师队伍对于高职院校旅 游管理专业而言, 是十分有必要的。教师只有在同时 具备专业的理论知识和实践知识的基础上才能在培 养专业旅游人才上实现效率的最大化。因此高职院校 在建设双师型队伍方面要在政策上给予支持, 态度上 给予鼓励, 为高职院校培养专业的双师型人才提供一 块肥沃的土壤, 同时高职院校建设双师型教师不仅能 够为学生带来更多的学习方面的帮助, 也能够为高职 院校的教育教学建设提供更大的助力。

\section{REFERENCES}

[1] Shi Xiaofeng. Responding to the Difficulty in the Construction of "Double-qualified" Teachers in Application-oriented Colleges with People-oriented Management Theory [J]. China Adult Education,2020(21):83-86.

[2] $\mathrm{Li}$ Wenwen. Research on the Construction of Double-qualified Business English Teachers Based on School-Enterprise Cooperation [J]. English in School,2020(40):47-48.

[3] Chen Tingyi. Research on the Professional Transformation of Tourism Teachers in Secondary Vocational Schools under the Background of "Double Teachers" [D]. Yunnan Normal University,2020.

[4] Wang Ying. Analysis on the Promoting Role of Vocational Skills Competition in the Construction of "Double-qualified" Teachers in Higher Vocational Colleges [J]. Shandong Animal Husbandry and Veterinary Medicine,2020,41(05):67-69.

[5] Wu Chuanbiao, Liu Huimeng. Current situation and cultivation countermeasures of vocational ability -A case study of college tourism management students $\quad[\mathrm{J}]$. China's collective economy,2019(36):165-166.

[6] Tu Liqiao, Huang Xiaorong. Journal of Higher Education,2019(22):146-149. (in Chinese)

[7] Cao Lin. Research on the Cultivation System of Core Literacy of Tourism Management Professionals in Higher Vocational Colleges under the Background of Lide Moral Cultivation [J]. Chinese Journal of Multimedia and Network Teaching (Mid-Term Issue),2019(11):109-110.

[8] He Yong. Policy Analysis and Path Research on the Construction of "Double-qualified" Teachers in Secondary Vocational Schools under the
Background of the Integration of Industry and Education [J]. Guangxi Education,2019(38):67$68+71$

[9] Liu Qingxue, Liu Ying. Research on the construction of "dual teachers" in applied independent colleges based on school-enterprise cooperation $\quad[\mathrm{J}]$. Communications World,2019,26(09):350-351.

[10] Xie Ruhuan. Research on the Construction of "Double Qualification" Teachers in Independent Colleges under the Background of Supply Side Reform -- Based on the Perspective of "3+1 SchoolEnterprise Cooperation" in the School of Information Science and Technology of Guilin University of Electronic Technology [J]. Guangxi Education,2019(19):95-96+127.

[11] Liu Siyi, Long Yan. A new model of teaching staff construction based on school-enterprise cooperation and modern apprenticeship system [J]. Family Life Guide,2019(05):176.

[12] Guan Yuting. Problems and countermeasures in the construction of "double-qualified" teachers in higher vocational colleges in China [J]. Journal of Henan University of Science and Technology,2018,38(12):51-55.

[13] Wang Shurun. High-quality -- the new kinetic energy of the construction of "double-qualified" teachers in the new era [J]. Occupation,2018(26):6465.

[14] Sun Yuanyuan. Research on the importance and countermeasures of the construction of "double professional" teachers in secondary vocational schools [J]. Times Education,2018(12):80+91.

[15] Zhou Xiaomei. Teaching staff construction in the context of school-enterprise cooperation: A case study of tourism management [J]. Journal of Jiangsu Polytechnic of Economics and Trade,2018(03):4446.

[16] Zhang Xiaoli, Wang Jinghua. Research on the Application of "Process Reengineering" Theory to the Construction of "Double Teachers" in the Transformation University [J]. Vocational and Technical Education,2018,39(17):63-66.

[17] CHEN Jie, LIU Tao. Research on the Course System of Tourism Management in Local Colleges and Universities $[\mathrm{J}]$. Journal of Anshun University,2017,19(03):64-67. 